


\title{
Masculino-femenino. \\ La representación del amor en el libro \\ El Cortesano, de Luys Milán
}

\author{
ISABEL MORANT \\ Universitat de València
}

\section{Resumen}

En el libro de El Cortesano, escrito por don Luys Milán —un noble valenciano perteneciente a la corte de doña Germana de Foix-, se dice que su autor se había inspirado en Il Cortegiano de Baltasar Castiglione, publicado en 1528. En efecto, en ambos textos la acción se desarrolla en el ambiente cortesano - en el libro de Castiglione transcurre en la corte de Urbino, y en el de Milán, en la valenciana-, entre los años 1526 y I536. En este último Cortesano, sin embargo, sorprenden las diferencias formales y de contenido, la teatralidad de la composición y, también, la forma carnavalesca, la exageración y la jocosidad, que eran propias de la literatura popular. Los cortesanos, que aquí aparecen con sus nombres y apellidos reales, se representan a sí mismos, hablando, como si de un teatro se tratara, de sus costumbres y valores morales. El tono de burla permite liberar la palabra y sirve también para marcar, junto con la crítica de las costumbres, los valores morales que se proponen, si bien de manera diferente para uno y otro sexo. Finalmente, la pluralidad de las voces que se expresan en el texto nos permite apreciar las discrepancias ideológicas y las tensiones morales que se daban en las élites valencianas.

Palabras clave: Identidades de los sexos, sexualidad, amor, matrimonio. 
Masculi-femeni. La representació de l'amor en el llibre El cortesano, de Luys Milán

\title{
Resum
}

En el llibre El Cortesano, escrit per Don Luys Milán, un noble valencià pertanyent a la cort de Germana de Foix i el seu segon marit, el duc de Calàbria, es diu que el seu autor s'havia inspirat en el Cortesano de Castiglione, publicat el I528. En efecte, com passa en el text italià, ambientat a la cort d'Urbino, en el llibre de Milán l'acció se situa a la cort valenciana entre els anys I526 i 1536. En aquest Cortesano, no obstant això, ens sorprenen les diferències formals i de contingut; la teatralitat de la composició i la forma carnavalesca, l'exageració i la jocositat, pròpies de la literatura popular. Els cortesans, que aquí apareixen amb els seus noms i cognoms reals, es representen a si mateixos parlant, com si es tractés d'un teatre, dels seus costums i dels seus valors morals. Pel que fa al to de burla, que permet alliberar la paraula, serveix també per marcar, juntament amb la crítica dels costums, els valors morals que es proposen. De manera diferent per a cada sexe. Finalment, la pluralitat de les veus que s'expressen en el text ens permet veure les discrepàncies ideològiques i les tensions morals que eren pròpies de les elits valencianes.

Paraules clau: Identitats dels sexes, sexualitat, amor, matrimoni.

Masculine-feminine. The representation of love in $\mathrm{El}$ Cortesano, by Luys Milán

\begin{abstract}
In the book El Cortesano, written by Luis de Milán, a Valencian nobleman of the court of Mrs Germana de Foix and her second husband the Duke of Calabria, it is stated that the author had been inspired by Castiglione's Il Cortegiano, published in 1528 . Indeed, just as the Italian story is set in the court of Urbino, the action in Milán's book takes place in the Valencian court between I526 and I536. In this 'Cortesano', however, the differences in form and content are surprising: the theatricality of the composition and the carnival form, the exaggeration and the humour more characteristic of popular literature. The courtiers, appearing here with their real names and surnames, speak for themselves, as if in a theatre, of their habits and their moral values. The tone of mockery, which facilitates expression, also serves to mark, along with the criticism of the courtiers' habits, the moral values they raise. Differently for
\end{abstract}


each sex. Finally, the plurality of the voices which appear in the text, shows us the ideological discrepancies and moral tensions that were characteristic of the Valencian elites.

Keywords: Identities of the sexes, sexuality, love, marriage.

\section{Introducción}

Hallándome con ciertas damas de Valencia que tenían entre manos el Cortesano del conde Balthasar Castillón, dixeron qué me parescía d’el. Yo dixe «Más querría ser vos conde [Castiglione] que don Luys de Milán por estar en essas manos donde yo querría star[»]. Respondieron las damas: [ $]$ Pues haced vos un otro para que halleguéys a veros en las manos [de las damas] que tanto os han dado de mano[»]. Prové ha hazelle y á ha llegado á tanto que no le han dado de mano, si nó la mano para levantalle. ${ }^{I}$

En el prólogo del libro titulado El Cortesano, escrito por don Luys Milán, un noble valenciano perteneciente a la corte de Germana de Foix, se dice que la obra, escrita hacia I635, había sido concebida a imitación de El Cortesano de Baltasar Castiglione, publicada en I528. Así pues, podemos suponer que el libro de Castiglione debía de ser conocido en Valencia, en su versión original o en la traducción castellana, publicada en I534, como se infiere del texto del enunciado, en el que se pone de relieve el interés de las damas en el conocimiento y lectura de la literatura cortesana. Esta edición se debe a un conocido poeta catalán, Juan Boscán, del cual sabemos que tenía relación con Valencia. En efecto, al igual que ocurre en el texto de Castiglione, cuya acción se sitúa en la corte italiana de Urbino, en El Cortesano de Milán la historia se sitúa en una corte renacentista, la formada en Valencia alrededor de dońa Germana de Foix y su segundo esposo, el duque de Calabria, entre los

I. Luys Milán, El Cortesano (I559), ed. de V. J. Escartí, con estudios introductorios de V. J. Escartí y A. Tordera, Biblioteca Valenciana, Ajuntament de València, Universitat de València, Valencia, 200I, I, p. I77. 
años I526-I536. La obra, sin embargo, no se publicaría hasta I559, un ańo antes de la muerte de su autor. ${ }^{2}$

En El Cortesano de Milán se destaca la forma teatral; los cortesanos aparecen aquí con sus nombres y apellidos reales, representándose a sí mismos en los espacios habituales de la corte, en el palacio de los duques o en una cacería, hablando con ingenio y gracia de temas cotidianos, del amor y del matrimonio. ${ }^{3}$ Se destaca también la forma carnavalesca, la exageración y la jocosidad, que sería propia de la literatura popular, y que permite burlar las normas morales establecidas en la sociedad; pero la libertad de palabra que ciertamente puede resultar chocante no sería contradictoria con el carácter normativo del libro, en cuyas páginas se debía de descubrir también la norma moral en él inscrita. Como el propio autor advierte ya en las primeras páginas del libro: «Y debaxo de sta alegria no calle philosophía muy de veras, que las burlas haze veras». ${ }^{4} \mathrm{Y}$, como se reconoce también en las palabras que dirige a los contertulios que ríen el ingenio de los burladores: «No son farças lo que vos hazéis. Pues de vuestras burlas se pueden sacar avisadas veras y de las veras avisadas burlas».5

$\mathrm{Al}$ igual que ocurre en el texto de Castiglione, el objetivo declarado de este Cortesano era la formación del perfecto caballero. Pero, al contrario de lo que ocurre en el texto de Castiglione, aquí no se habla expresamente de formar a la dama. Sin embargo, la figura de la mujer aparece también representada en relación con la figura masculina, marcada por la diferencia sexual y los valores que se suponen específicos de la feminidad. En este sentido, el texto escrito en Valencia se distanciaría de los textos de Gracián como El Héroe, el Discreto o el Oráculo manual, en los que «no hay lugar para las mujeres». ${ }^{6}$

2. Ibidem, pp. II-38.

3. Antoni Tordera, "Drama i estratègies escèniques en El Cortesano", en Milán, El Cortesano, I, pp. 99-I25.

4. Milán, El Cortesano, i, p. 256.

5. Ibidem, p. 357.

6. Maria Teresa Ricci, Du «cortegiano" au "discreto»: l'homme accompli chez Castiglione et Gracián. Pour une contribution de l'histoire de l'honnête homme, Honoré Champion, París, 2009, p. 320. 
En el libro de Milán se destaca, por último, el tono de la polémica moral que vemos expresarse en la literatura de la época, en torno a las identidades de los sexos a la moral del amor y del matrimonio. En este sentido se mostrarían las semejanzas — y también sus discrepanciascon las representaciones y la doctrina moral contenida en la literatura conocida en los ambientes intelectuales de la corte: desde los cuentos y las novelas de caballerías hasta los tratados normativos, significados en la obra de los humanistas, en Erasmo o en Vives, o en los tratados morales escritos por los sacerdotes católicos.

\section{Los conflictos del amor y del matrimonio}

Salió el real duque de Calabria y la reyna Germana ricamente vestidos de terciopelo carmesí, broslados de hilo de oro: por invicción, muchas matas de retama, que los granos d'ellas eran muy gruesas y finas perlas orientales de gran valor. Diziendo a todas las damas.

Mi invinción traigo por mote.

A esto respondió la reyna con unos celos cortesanos y dixo:

La retama es mi amor y vos d'ella el amargor.

Dixo el duque sonriendo:

Mi amor es la retama, por mostrar sobrado amor. Que en mi no stá el amargor, sino en mi dama. ${ }^{7}$

Dividido en seis jornadas, el libro comienza con una cacería, presidida por los virreyes: el duque de Calabria y doña Germana, acompañados por los nobles que formaban parte de su corte en Valencia. Estos aparecen ricamente vestidos, como corresponde a su nobleza, todos llevan un escudo con un mote relativo a su pareja. En estos textos, que funcionan como una invectiva, se critican las costumbres que se dicen propias de los hombres, y de un modo particular de los maridos que descuidarían el afecto y la fidelidad debidos a la esposa. Así se significa en el texto del enunciado, tanto en las palabras de la virreina que acusa

7. Milán, El Cortesano, I, pp. 179-I80. 
los celos del marido como en la burla del duque que le devuelve la invectiva. Así se significa también en las palabras de un criado que reconoce ser el alcahuete del duque: «a la reyna no le pese que yo sea alcahuete de mi señor, los alcahuetes son necesarios y habiendo tantos de ese oficio, más vale que yo lo sea que no el reverendo canónigo Ster... etc.». ${ }^{8}$ En el desfile de los cortesanos, que hablan con desenvoltura del tema, se podría deducir la naturalidad de las costumbres masculinas de amar fuera del matrimonio. Así se significa también en este otro mote que porta una dama, con el que se podría entender que todo el mundo conoce estos asuntos: «Vi que vi». Y lo que dice que vio es "como la señora daña Mencía oyo al canónigo Ster, que havía traýdo a Beatriz de Gilote encomiendas de parte de don Luys Vique, su marido».?

En estas escenas se pone de relieve la contradicción del amor cortés, que hundía sus raíces en la literatura medieval, en las conocidas imágenes del perfecto amor entre damas y caballeros que, sin estar casados, podían estar unidos por un libre y puro amor, exento de culpa, por la renuncia de la carne. Este discurso, sin embargo, siempre había sido sospechoso a los ojos de los moralistas más estrictos, particularmente de los sacerdotes, que cuestionaban la bondad de un amor cuya perfección difícilmente podía ser alcanzable por los humanos amadores. Esta tensión moral es la que se significa en los libros de caballerías, conocidos y apreciados en esa época. Así puede verse en el famoso Tirant lo Blanch, de Joanot Martorell, donde se muestran los esfuerzos del valiente caballero enamorado de la princesa Carmesina, que debía luchar con denuedo por contener los deseos de la carne; igual que aparecen las dudas de la joven, que debiendo contener la pasión del caballero notaba en ella las pulsiones del amor, que la criada - Plaerdemavida - se encargaría de excitar. ${ }^{10}$

Esta sospecha del amor es la que se reproduce ahora en el libro de El Cortesano, en el cual aflora la contradicción de estas prácticas con la

8. Ibidem, p. I8I.

9. Ibidem, pp. I8I-I82.

io. Joanot Martorell, Tirant lo Blanc (I490), ed. de V. Gómez, Edicions Alfons el Magnànim, IVEI, Valencia, I990. 
norma moral que prescribía la contención del amor en el matrimonio. Este, se pensaba también, debía ser una unión afectiva y constante. Como se sostiene en el texto que sigue:

Dixo Doña Castellana Bellvís: que me han dicho que por no ser celosa mi cuñada, dize su marido que no es amorosa, y va a buscar el amor fuera de casa. Y porque sea más casero no debe dexar un día en la semana de ser celosa, que ha maridos que se desmandan los celos los enfrentan y así continúa los hombres volverán a casa y al amor de la mujer como deben. ${ }^{\text {II }}$

Así pues, el problema que aquí se plantea es el orden $-\mathrm{y}$ el desorden- de la sexualidad masculina, del deseo que, concebido como una inclinación natural en los hombres, fuertes, viriles y procreadores, podía percibirse también como una debilidad moral de sexo masculino, el cual, marcado por el estigma de la carne, heredado del pecado original, se resistía a seguir la norma de la contención del amor en el matrimonio. ${ }^{12}$

Esta tensión moral es la que aparece en El Cortesano, en la crítica que se dirige a los hombres que, bajo la capa del perfecto amor, entre parejas no casadas, ocultarían el incumplimiento de las leyes del matrimonio. De este modo se significa en el texto que sigue, en la crítica de una esposa airada que acusa la mala conducta del marido: "Por trobar vuestras maldades, digo en verso las verdades, que merecéis que yo diga, que vestís, muger y amiga, y ¿quién os hizo paxarero caballero? ¿quién os hizo paxarero caballero?». ${ }^{13}$

En este Cortesano, en efecto, se reproduce el debate sobre el amor y el matrimonio y la fidelidad conyugal que vemos expresarse en la literatura humanista. En los Coloquios de Erasmo, publicados en la década de I520, se critica la doctrina moral de la Iglesia que, con el objetivo de ensalzar las virtudes del celibato, habría exagerado la sospecha de la sexualidad que sería natural y necesaria en los humanos, que destinados a procrear-

II. Milán, El cortesano, I, p. I85.

I2. Georges Vigarello, «L'invention de la virilité, de l'Antiquite au Lumieres», en A. Corbin, J. J. Courtine y G. Vigarello, dirs., Histoire de la virilité, Seuil, París, 20II, pp. 8-9.

I3. Milán, El Cortesano, i, p. I88. 
se, podían gozar de los placeres de la unión sexual con la esposa. Pero en estos mismos textos se pone de relieve el desprestigio del matrimonio, percibido como una institución necesaria y útil a la sociedad, también como un destino social, impuesto a los hombres que perderían la libertad propia de los solteros al casarse. Así se muestra en el lenguaje de los Coloquios, en los que el matrimonio se representa como un yugo, una soga al cuello o un cabestro, que muchos hombres no querrían llevar. ${ }^{\mathrm{I4}} \mathrm{Y}$ lo mismo se pone de relieve en El cortesano, en las imágenes de las parejas que se dicen mal casadas, que reconocen su distancia afectiva y su desinterés respecto del matrimonio:

El marido mal casado canta en otro gallinero.

Hay, señoras si se usase

Quien mal marido tiene que lo dexasse. ${ }^{\mathrm{IS}}$

Esta percepción del amor y del matrimonio es la que aparece de manera ejemplar en el libro con la historia de Petrarca, del cual se dice que, a pesar de haber sido dispensado por el papa de la orden sacerdotal a la que pertenecía para que pudiera casarse con su amada Laura, no habría querido someterse al orden matrimonial. En esta historia —irreal — se pone de relieve lo que venimos diciendo sobre la disyunción entre el amor y del matrimonio: la libertad del amor, reconocido y magnificado en los textos del poeta como un placer — sensual o espiritual- preferible al matrimonio, del que se destacan los deberes del marido. Se dice en el texto:

Por eso no usó de casar un sabio que yo diré: El Petrarcha siendo canónigo de Padua, dispensava el papa que casase con dońa Laura, por quien él mostró estar tan enamorado d'ella, como en sus Triunphos y sonetos se vee..., Pero: él no queriendo casar respondió al Papa: No quiero trocar los placeres de la de l' amiga, por los enojos de la muger. ${ }^{16}$

I4. Isabel Morant, Discursos de la vida buena. Matrimonio, mujer y sexualidad en la literatura humanista, Cátedra, Madrid, 2002, pp. 27-39.

I5. Milán, El Cortesano, I, p. 195.

I6. Ibidem, p. 239. 


\section{I.I. ¿De qué se ríen los cortesanos?}

En el libro de El Cortesano no se habla abiertamente del adulterio esta voz no aparece en el texto- - Sin embargo, se percibe como una práctica tolerada en la sociedad cortesana. Esta 'realidad' es la que se reconoce también en el libro de Lucien Febvre, ${ }^{17}$ compuesto a partir de la lectura de los cuentos del Heptamerón escritos por Margarita de Navarra en la década de I530. En ellos se describe la sexualidad desbordante de los hombres, de los caballeros, que siendo servidores de una dama casada luchaban inútilmente por esconder la sexualidad irrefrenable que les impulsaba a desear, en el sentido carnal, a su amada. Pero en estos textos se mostraba también la tolerancia de la autora, de la humanista, que, lejos de condenar de manera absoluta las inclinaciones de la sensualidad, aconsejaba a las mujeres que no se dejaran engañar por la apariencia sino que, conociendo la verdadera naturaleza de los hombres, los comprendieran, para poder disfrutar así —ellas también- de las delicias del amor y de los placeres, no solo espirituales. ${ }^{18}$

En este sentido Febvre se interesa por el estudio de la vida privada de Francisco I, el rey de Francia, hermano de la reina, cuyos adulterios eran bien conocidos. Pero cabe decir también que el obispo de París, obligado a mostrar el poder de Dios que él representaba, debía amonestar al rey e imponerle la penitencia que perdonara sus pecados. En estas ocasiones, que se repetían de tanto en tanto, el rey, vestido con un humilde hábito debía ir caminando hasta la catedral para recibir la absolución del propio obispo. Sin embargo, en este recorrido el rey penitente era reconocido y aclamado por los súbditos, que percibían su humanidad, a la vez que los hombres pecadores percibían sus propios deseos y el perdón que la iglesia les otorgaría. ${ }^{19}$

17. Lucien Febvre, Autour de l'Heptaméron. Amour sacré, amour profane, Gallimard, París, I944.

I8. Morant, Discursos de la vida buena.

19. Febvre, Autour de l'Heptaméron. 


\section{Misoginia y negación del amor}

Sabéys quién es el dios d' amor nombrado?

Tené por fe que es vuestro mal desseo

Por desear desvergonzadamente.

Desnudo va quien es desvengonçado. ${ }^{20}$

El amor elevado a los altares en la literatura, que hundía sus raíces en el pasado medieval, sería denostado en los mismos textos, en los que se ponía también de relieve la influencia de la doctrina moral de las Iglesias cristianas, contenida en los escritos de los sacerdotes, pero también en los tratados de los moralistas más estrictos, como era el caso de los escritos de Vives. En ellos se destaca la elevación del tono moral reflejado en la desconfianza en la condición humana y en la sospecha de la humana sexualidad. Este pesimismo moralizante es el que se reproduce en las imágenes negativas de los hombres que, arrastrados por sus deseos o locos de amor, padecían todos los males físicos y morales que se conocen: el mal de los franceses o la pérdida del prestigio y autoridad propia de los hombres moralmente superiores y viriles. Y esta desconfianza es la que se representa en las imágenes de las mujeres que, siguiendo el pensamiento de la misoginia, se describen de manera negativa, marcadas por la herencia de la madre Eva, como un peligro para el hombre, débil o debilitado por sus pasiones carnales. La retórica de la misoginia se compadece con la imagen del hombre que, carnal por naturaleza, necesitaría a la mujer, que aquí se representa como un objeto sexualmente deseable pero también débil, moralmente incierto y, por tanto, peligroso para los hombres, que temerían su influencia y dominio. Lo vemos en el texto que sigue, en la advertencia que el autor del libro dirige a los hombres incontinentes contra el engaño y la mentira de las mujeres:

Quiero decir, que yo dire las verdades a los penados amadores para que sepan guardarse de las mentiras que se dan a entender, confiándose mu-

20. Milán, El Cortesano, I, p. 264. 
cho para seguir lo que les haze sospirar, como a Joan Fernández cada día le sigue que se confía merescer en amores tanto como desmerecerse en dexarse engañar de una tercera, que le da a entender ser verdades las mentiras que le dize para engańarle y no la quiere creer de las verdades para desengańarle, como oyreis en este cuento que os dire. ${ }^{21}$

Este temor es el que se representa en las historias que se cuentan del pasado referentes a las desgracias sufridas por los hombres, los cuales, víctimas de sus propias pasiones, habrían sido dominados o engańados por las peligrosas mujeres. Así se muestra en las imágenes de los tristes caballeros enamorados de las damas que se ven burlados en su honor por aquellas que admiten el homenaje de otro caballero. En el libro, tomando como referencia los fracasados amores de una conocida pareja medieval, se puede leer:

Don Luys Milán: ¿̨no’s acordáys de los amores de Belerma y Durandarte? Que siendo desterrado por mandato de su emperador Carlo, y bolviendo a la corte perdonado, halló a Gayferos servidor de Belerma, sin haber dado él ocasión; y quexándose d' esta trayción dexó de servirla, diziendo que: "por no çufrir ultraje moriré desperado", mostrando que la dama ha de mostrarse enojada si la sirve otro caballero, si ya su servidor no le ha dado ocasión para despedille, si le ha sido desleal. ${ }^{22}$

En estos textos, sin embargo, se pone de relieve que el problema de la mujer no era tanto el deseo desbordante de la sexualidad que se significa en los hombres, como la debilidad — física y moral- que se mostraba en las conductas. Tal puede verse en la imagen de esta Bellerma que, solicitada por Gaiferos, mostraría la veleidad e inconstancia que sería propia del sexo femenino. Dicho de otro modo: la imagen de la mujer que se destaca en estos textos, como en los moralistas de la época, refiere más bien la debilidad física y moral que serían propias del sexo femenino, frente a la acción y la iniciativa que corresponderían a

2I. Ibidem, p. 26I.

22. Ibidem, p. 283. 
los hombres viriles, en cuyas acciones se mostraría la fuerza - y el desorden- de la masculinidad. Como se puede apreciar en la figura del seductor Gaiferos, cuando compite con otro hombre por la posesión del objeto deseado.

En el texto, sin embargo, la imagen negativa de la mujer será cuestionada por una parte de los contertulios, en particular por las propias mujeres, que denuncian la mala fe de los hombres, de los misóginos, que sospechaban falsamente de ellas. Así se dice en el escrito de Belerma a su amante:

¡Buelve, buelve caballero!

No quieras desesperarte, que en tu amor tan verdadero siempre serás tu el primero, Durandarte. Durandarte.

Pero Durandarte, herido en su amor, recuerda la inmensidad de la falta femenina y el abandono que por ello merece Belerma:

$Y$ aunque en damas no's tan mal

No tener ley en no veros, siendo yo tan leal, en vos fue más que mortal pues amastes a Gayferos. ${ }^{23}$

En esta historia medieval se pone de relieve la mentira del amor, que, representado como un ideal en la literatura cortesana, se muestra ahora como un producto de la imaginación —o como un sueño—imposible de alcanzar por los humanos, los cuales, arrastrados por la pasión del amor, sucumbirían al trato y a la unión con la mujer, representada, de manera contradictoria, como un objeto deseable que se revelaría como un sujeto inferior e imperfecto con el que el hombre, superior, no debería rozarse. Esta imagen concuerda con el pensamiento de los moralistas, que siguiendo la doctrina moral de la Iglesia privilegiaban la moral de la renuncia, así como el mantener las distancias y un trato

23. Ibidem, pp. 292 y 297. 
frío con las mujeres, aun en el matrimonio. Esta idea puede verse, por ejemplo, en la obra de Vives Los deberes del marido, donde en la línea marcada por las religiones se predica una mayor diferenciación y una relación afectiva más distante entre hombres y mujeres, e incluso se comprende la renuncia a la práctica del sexo en el matrimonio. ${ }^{24}$

En este Cortesano también se pone de relieve la otra cara de la moneda. La negación del amor alentada en las mujeres que, siguiendo como deben las normas del buen amor, escritas por los hombres, acusaban la inmoralidad de aquellos que incumplían sin recato las normas de la contención sexual. Así, por ejemplo, se dice en el texto, en las palabras de una mujer, que denuncia los requerimientos de los enamorados caballeros que, aunque no podían casarse con su dama, querían ser tratados como maridos. "Don Luys Milán: con un cuento quiero alabaros. Quando yo era dama de la reyna, iva servydor un cavallero, gran músico de una de palacio, amiga mia, y quando le tañya atatapávase los oýdos, diziendo: No se debe oyr, lo que n'os de agrasdecer». ${ }^{25}$

En esta representación de las cosas destaca la violencia del conflicto que se ocultaría bajo la capa de la cortesía; la relativa libertad que se otorgaba a los hombres que, amparados por el privilegio de la virilidad o bajo la capa de los méritos desplegados en el servicio — en el amora las damas, se sentían merecedores de los favores sexuales tanto de las amigas como de las esposas, si bien no siempre les eran concedidos. Así, se dice, lamentando la actitud de los hombres: «Vos y ellos querríades que el amor os truxesse con el plato de vuesto apetito, la perdíz que desse'ays comer en amores. Y si esto no se haze, luego decís que la amiga es enemiga, pues no cumple vuestros deseos». ${ }^{26}$

La disputa de los sexos se interrumpe de manera inesperada por la aparición de un extraño personaje vestido a la usanza de un caballero medieval, que se presenta ante la concurrencia con un extrańo nombre: Miraflor de Milán. Este personaje, que cuenta una rocambolesca histo-

24. Morant, Discursos de la vida buena, pp. 247-262.

25. Milán, El Cortesano, i, p. 30 I.

26. Ibidem, p. 309. 
ria sobre la huida del dios Cupido expulsado de Valencia, dice ser su enviado del amor para dar un mensaje de esperanza a los cortesanos que viven desenamorados. Y tras esta declaración del caballero - que no es otro que el autor, don Luys Milán, disfrazado para dar una lección a los cortesanos que viven en conflicto- el duque ordena que la corte se retire a descansar y que todos se vuelvan a reunir al día siguiente, a la hora misma y en el mismo lugar, para seguir tratando sobre el tema.

\section{I. La risa de las mujeres}

Viendo estas escenas, ciertamente hilarantes, nos preguntamos de qué se ríen las mujeres. Las mujeres que, maltratadas en los textos que reproducen el discurso de la misoginia, hacen burla de los hombres que incumplían las normas del amor que ellos mismos se habían dado. De qué se ríe una tal dońa Margarita de Peralta, cuando un día ve a su amante triste y suplicándole no ser tratado como Laura hacía con su Petrarca: «que lo goverva como a caballo bien enfrenado, que en desmandarse de confiado le daba una çofrenada, y en acovardarse de triste, le aflojaba la rienda». Dońa Margarita se burla de él diciéndole: «Alégrate, que pues escrives como el Petrarcha yo leeré tus obras como Laura». ${ }^{27}$ En efecto, en estas palabras destaca la contradicción que contenían las obras del poeta, en la imagen de los hombres que, bajo la capa del perfecto amor, se revelarían como vulgares amadores. $\mathrm{O}$, dicho de otro modo, el conflicto moral existente entre el deseo del amor que se mostraría en las demandas —o en los ataques — de los hombres, que justificarían sus actos, y la lógica moral de las mujeres, que rechazarían sus demandas.

Este conflicto de libertades se percibe también en los textos de Margarita de Navarra, en los cuales se aconseja a las mujeres que no se dejen

27. Ibidem, p. 320. Lucía Dussault, «¿De qué se ríen las mujeres? Un análisis de El Cortesano de Baltasar de Castiglione», en II Jornadas de Estudios de Género y Feminismos, Facultad de Humanidades y Ciencias de la Educación de la Universidad de la Plata, La Plata, 200I, pp. 32-37. 
engañar por las mentiras de los hombres y que, en todo caso, frente a las libertades de los maridos, respondan ellas con la misma desenvoltura. Así, se dice: "He aquí, señoras, una historia que os cuento gustoso para que os sirva de ejemplo y, cuando vuestros maridos os pongan cuernos de cabrito se los pongáis de ciervo». ${ }^{28}$

Claro que esta libertad de palabra y disidencia debía de comprenderse en aquellas mujeres que, viviendo en la corte y pertenecientes a la nobleza, podían enfrentar con cierta facilidad a los hombres, que aun pertenecientes a su misma clase, serían inferiores a ellas por su rango familiar, por el lugar que ocupaban en los cargos de la corte, etc. Este privilegio de clase, si podemos llamarlo así, se muestra en los escritos de la reina, más partidaria de las formas del amor cortés con un amigo y servidor que del amor obligado con un marido que podía imponerle su autoridad. ${ }^{29}$

\section{Nostalgia del pasado y construcciones de la norma sexual}

\section{Dixo la reyna}

Perdido se ha l'amor en Valencia, aunque no es una excelencia.

Respondió el duque:

Ni menos perdido le han, un'alteza y un Milán. ${ }^{30}$

En la jornada sexta y última de El Cortesano, los nobles, reunidos en el palacio del duque de Calabria, lamentan la pérdida de las buenas y viejas costumbres cortesanas. Como dice la reina doña Germana: «Perdido se ha l'amor en Valencia»; a lo que contesta su marido, mostrando sus recelos, que la reina no tiene motivos para quejarse de su Milán. Este Milán al que se refiere el duque era don Pedro Milán, primo de don Luys, autor del libro, que al parecer era el amigo —el servidorde la virreina. En estas escenas se pone de relieve la nostalgia; la mirada que se proyectaría hacia un pasado que se podría recuperar para cons-

28. Morant, Discursos de la vida buena, p. 267.

29. Ibidem, pp. 267-272.

30. Milán, El Cortesano, I, p. 532. 
truir el presente, que se considera degradado por la culpa de los hombres, de los caballeros que habían olvidado las formas y las cualidades propias de los buenos cortesanos:

Ya véys quan infamada esta Valencia, que no hay amor en ella. Y esto no viene sino por un gran descuydo que se tiene, que no quieren ser buenos officiales los cavalleros en su oficio que es saber a maestro en todo lo que no debe ygnorar un cavallero, que para ganar buen nombre, críamos naturaleza y quiere que se ayude el hombre..$^{31}$

Con este diagnóstico el duque manda que los cortesanos cumplan con el objetivo marcado para la reunión: construir el modelo del perfecto caballero y de la dama, en correspondencia con la figura de aquel: «Y tornando a nuestro propósito, para que el amor se cobrasse en Valencia sería menester hacer leyes para algunas damas, que no se descuydassen de hacer lo que deben. Y a los cavalleros que supiesen cómo las han de servir...».32

De este modo, en las leyes que se aprueban por separado para los hombres y las mujeres, los valores del pasado se proyectarían en el presente. ${ }^{33}$ Lo muestra el lenguaje y las formas de la cortesía que se usan para construir el nuevo modelo que ahora se pretende para los matrimonios. Pues no debemos olvidar que las damas y los caballeros presentes en las escenas, a los que el libro está dedicado, eran casados.

Así, en la primera de las leyes que se dirigen a la formación de los hombres, se inscribe, una vez más, la representación de la sexualidad masculina, la iniciativa - $\mathrm{O}$, si se prefiere, el ataque — que en el amor sería propia de los hombres viriles, para los cuales en consecuencia se dicta la primera norma: la obligada de la contención del deseo y la constancia en el amor, que se debe dirigir a una sola mujer, a la amiga o a la esposa:

31. Ibidem, pp. 533-534.

32. Ibidem, pp. 534-535.

33. Peter Burke, Los avatares de "El Cortesano». Lecturas y lectores de un texto clave del espiritu renacentista, Gedisa, Barcelona, 1998. 
Sobre esto hizo el duque una primera ley:

Lo que stá en la ley sea ley:

que sospire el servidor

y si no 'es sospirador

tenga con su dama ley .

Y será lo que yo 's digo:

que requiebros nunca diga

sino solo a su amiga.

Sino, denle al enemigo. ${ }^{34}$

$\mathrm{Y}$ para los hombres inclinados al amor —o para los irreductibles concupiscentes - se prescribe que no se relacionen sino con mujeres de calidad —es decir, con damas de su misma condición social—, que nunca pretendan conocer carnalmente a aquellas con las que no se pueden casar y que no persigan a las jóvenes, como se señala en aquellos que, de manera contraria a lo que corresponde a su nobleza y su condición social, son moceros y no dameros.

En cambio, en las leyes que se dirigen a las mujeres se significa la pasividad sexual que se supone como propia del sexo femenino, cuya debilidad física se reflejaría en una mayor retención del deseo y una timidez en las expresiones del amor. En consecuencia, la norma les recordaría la mayor obligación de poner freno y distancia a los deseos de los hombres. Se explica en el texto diciendo que las mujeres, que conocen la ley, deben saber que todo lo que pueden consentir a los hombres que no son sus maridos es que suspiren: «si las damas lo son, no deben de çufrir a los cavalleros que digan a las que sirven requiebros sin suspirar». O lo que es lo mismo: «que requiebro nunca diga sino sólo a su amiga». ${ }^{35}$

En el debate que sigue a esta ley se pone de relieve el juicio - $-\mathrm{ol}$ prejuicio- de la misoginia; la sinrazón denunciada por los hombres que, obligados por la misma ley a servir a las mujeres y respetar su voluntad, se quejan de la autoridad y dominio que en el amor se conce-

34. Milán, El Cortesano, I, p. 537.

35. Ibidem, p. 538. 
dería a las mujeres, a las amigas que les negaban sus favores. Lo cual se dice también no podía ocurrir a los casados que, amparados por el débito conyugal, podían decidir a su antojo. El rechazo de esta norma se representa así en el texto que sigue:

Luego salió con un agravio Don Juan Cardona y dijo: Señor: yo stoy maravillado de la dama que por haber la primera d' ellas sojuzgado al primer hombre, quieren tener el mando sobre nosotros, que nunca mejor se dijo que dezille palomando, haciendo al hombre palo y a la mujer mando. Y no lo digo por los casados, que no stán d' esto agraviados, sino de los por casar, que mejor parecería no fueran maltratados los que no pueden llegar con quien aman a ser casados..$^{36}$

En el texto se expresa también la razón contraria de los cortesanos que defiende la necesidad y pertinencia de la norma, cuyo propósito no era socavar la autoridad de los hombres, como temían los misóginos, sino contribuir al orden moral de la sociedad, contando con las mujeres. Esta razón se expresa en el texto desmintiendo el argumento de los que temen la influencia y el poder de las mujeres, cuyo "mando» se suscribiría a hacer cumplir la norma de la continencia sexual, como queda claro en el texto que sigue:

Mucho se ha maravillado el seńor Joan Cardona. Y á quedado una flor de maravillas que huele bien los que ha dicho y parece mal, pues no se usa, Temiendo stoy que se han de secar sus flores a la salida del sol de mi razón que ya salle, y digo que del palomando que ha dicho lo mejor d' este nombre es que el hombre sea palo para sostener el cuerpo de los trabajos que tiene el deseo del amor y la mujer ha de ser mando para moderar su mal desear de los apetitos desmesurados que vuestro Cupido tiene. Y si vuestra axcellencia le peresce que yo he ganado este palomando, que es tener nosotras el mando para que no se desmanden los malos desseos de los que nos sirven, póngase en la ley que se ha de hacer. ${ }^{37}$

36. Ibidem, p. 543.

37. Ibidem, p. 544. 
En este Cortesano ciertamente se desmiente la inversión del poder, suscrita por los historiadores que, leyendo al pie de la letra los textos del amor cortés que hablan del hombre como amante servidor de las damas, imaginan un mundo medieval igualitario, avant la lettre. En el libro, sin embargo, se pone de relieve que la igualdad entre los sexos no era pensable en esa sociedad. Lo pensable era la diferencia sexual, que se expresa de manera negativa en la retórica de la misoginia, pero también en positivo en el discurso de la excelencia moral que se significa en los textos que refieren las virtudes —específicas - del sexo femenino. Este pensamiento es el que se significa en las palabras del duque de Calabria, el cual, tomando partido por las mujeres, explica así las razones por las cuales las mujeres merecen la confianza y el homenaje de los hombres:

Por alta place la dama que bien mandado manda, pues que no se desmanda: mande la buena fama. Quiero dezir, señores, que el mando sté en mugeres por moderar plazeres que gastan los amores. ${ }^{38}$

Esta moral es la que se mostraría en la figura de la perfecta dama, representada en esta tal dońa Margarita de Peralta, de la que sabemos que era la amiga de don Luys Milán, el autor del libro y el encargado por el duque de construir el modelo del perfecto caballero, que él mismo representa en el libro.

$\mathrm{El}$ debate de los sexos se interrumpe en este momento, con una nueva aparición del personaje conocido como Miraflor de Milán, que se dice enviado por el dios Cupido e informa de que este, junto con su madre, la diosa Venus, promete volver a Valencia: "para que con el vuelva el amor a la ciudad y se ponga fin al conflicto de los enamorados».

38. Ibidem. 
Y con esto el duque, que «rió mucho» con la disputa de los cortesanos, da por finalizada la escena y dice:

Señores: nunca fue mejor batalla que los muertos son de risa y los bivos de amores quedan cautivos. Las mesas están paradas para cenar, vayánse luego a sentar, porque mientras cenaremos, alabanzas oyremos de las Damas de Valencia... que cantaran todos mis cantores. ${ }^{39}$

\section{I. Las mujeres en las pasiones de los hombres}

En el libro de El Cortesano se pone de relieve la función moralizadora de las mujeres, que ya estaba presente en la literatura de la Edad Media y que ahora se desarrolla ampliamente en los libros de los autores que, distanciados de la tradición de la misoginia — del hablar mal de las mujeres_-, sostendrían una opinión más matizada y sobre todo pragmática, expresada en los textos interesados en poner de relieve las cualidades femeninas. Este cambio de paradigma aparece ya en la literatura caballeresca, en las imágenes de las damas que, lejos de la imagen de la vieja madre Eva, se representan de manera positiva en la imagen de María - lo cual, a decir de los moralistas, debía de servir mejor para elevar la moral de las mujeres_- Esta pragmática es la que se expresa ahora en El cortesano, en el elogio de las cualidades morales de las mujeres que, como dońa Margarita de Peralta, merecerían la confianza de los hombres que valoran su influencia. Salvando las distancias, este discurso se sostiene también en los libros de los moralistas, sacerdotes o seglares, que escriben para la formación de las mujeres. Tal era el caso de Juan Luis Vives, cuya obra La formación de la mujer cristiana, escrita en latín, fue traducida y publicada en castellano en 1528 por Juan Justiniano, un caballero de la corte de Carlos V..4

39. Ibidem, pp. 576-577.

40. Isabel Morant, «Hombres y mujeres en el discurso de los moralistas», en I. Morant, dir., Historia de las mujeres en España y América Latina. II. El mundo moderno, Cátedra, Madrid, 2005, pp. 5I-80. 
En esta literatura, sin embargo, se sostiene el desequilibro de la norma sexual, cuyo peso y obligatoriedad recaerían del lado de las mujeres. La función de estas nunca sería pensar o producir la norma, sino someterse a la ley dictada y avalada por los hombres superiores: tanto por los moralistas que escriben, como por los padres, los maridos o los hijos, a los que corresponde la guardia y custodia de la moral femenina. En cambio, en los hombres, reconocidos como responsables de sí mismos, la norma moral apelaría a su voluntad de perfección, a un código de caballero, cuya nobleza, ciertamente, se mostraría en el cumplimiento de las leyes establecidas. Pero la preeminencia sexual -y social- permitía en ellos una libertad mayor. En este sentido podemos preguntarnos hasta qué punto la influencia y el poder moral de las mujeres podía ser real y efectivo, hasta qué punto la moral de las mujeres podía ser compartida por los hombres, y hasta que punto las mujeres fueron influyentes en los hombres, en los maridos, cuyo poder y nobleza venía avalado tanto por el sexo como por las leyes. Y podemos preguntarnos también si no es posible que la moral que se expresaba en los textos funcionara en realidad en un solo sentido, para formar a las propias mujeres, más que a los hombres. En ellas, la sociedad y las familias - en particular, los hombres, los maridos- querían ver reflejados los valores que servían para marcar la dignidad y la autoridad moral y el gobierno, que correspondía ejercer a las élites masculinas. En ellos, por otro lado, parece alimentarse la nostalgia de la libertad perdida en el matrimonio y la resistencia a abandonar la costumbre de tener mujer y amiga. En las mujeres, en cambio, socialmente autorizadas a reprender las costumbres de los maridos que se dicen traviesos, se alentaba el desengaño y el sentimiento de dominio y la injusticia de los hombres.

Por último, en El cortesano escrito en Valencia se ponía de relieve la voluntad de las élites sociales de ordenar las conductas sexuales de los hombres, en la línea marcada por Norbert Elías en sus trabajos sobre la civilización de las costumbres. En este libro, sin embargo, se destacan las continuidades y las resistencias de un modelo normativo que hundiría sus raíces en el pasado para producir un presente diferente. Un modelo que, en el caso que nos sirve de referencia, se construye sobre 
las cenizas de un pasado marcado por la obsesión de la sexualidad, la diferencia de la moral sexual y la separación de los sexos. Marcado, pues, por la continuidad del conflicto de los sexos. 